Article

\title{
The Impact of the Sustainability Principles on the Strategic Planning and Reporting of Universities. An Exploratory Study on a Qualified Italian Sample
}

\author{
Primiano Di Nauta ${ }^{(}$, Enrica Iannuzzi * ${ }^{-}$, Michele Milone and Claudio Nigro \\ Department of Economics, University of Foggia, 71121 Foggia, Italy; primiano.dinauta@unifg.it (P.D.N.); \\ michele.milone@unifg.it (M.M.); claudio.nigro@unifg.it (C.N.) \\ * Correspondence: enrica.iannuzzi@unifg.it
}

Received: 3 August 2020; Accepted: 1 September 2020; Published: 4 September 2020

check for updates

\begin{abstract}
Strategic Plans (SPs) and Sustainability Reports (SRs) represent institutional communication tools implemented by universities to demonstrate their adoption of sustainability and sustainable development goals (SDGs of Agenda 2030) as drivers in their strategic planning processes. These tools make the adopted strategies and operations visible and easily understandable to stakeholders, highlighting the university's commitment to a new balance between business, environment, and the social sphere. Moving from this premise, with the aim to evaluate the degree of transposition of sustainability and sustainable development principles into the Italian university system, we propose an exploratory research on universities' institutional declarations, in the form of the SRs and SPs available on their web sites. To this aim, we conducted a content analysis aiming at a preliminary phase of text coding, based on a set of analytical categories-pillars-namely Education and Learning, Research, Operations and Governance, and External Leadership. The work has allowed us to identify: an interesting extent to which the sustainability principles have been transposed into the Italian university system, with particular regard to the third category of Operations and Governance (36\% of coded segments in SRs and 32\% of coded segments in SPs); a considerable awareness of universities of their key role played on the sociopolitical and economic levels for the diffusion of the Agenda 2030 within civil society.
\end{abstract}

Keywords: sustainability in universities; agenda 2030; sustainable development goals; institutional communication tools; strategic plan; sustainability report; sustainability commitment

\section{Introduction}

In recent decades, political and socioeconomic actors have recognized sustainability and then sustainable development (SD) as one of the greatest and most promising challenges of the twenty-first century [1-4]. SD is now a common essential principle driving the adoption and implementation of aware behavior by all social actors actively participating in the socioeconomic and environmental development of a territorial context. This means that the SD process is characterized by mixed and diverse interactions among actors, both institutional and noninstitutional, contributing to defining the constraints and the rules for ensuring intragenerational and intergenerational equity.

At the same time, while governments develop national strategies and approaches to support the achievement of the SD goals, organizations are playing their own roles in achieving and amplifying value creation processes. [5,6].

Within this scenario, universities fulfil the socially important role of institutions that perform a public function in the service of the national community, and other social realities that operate in the same territorial area, "especially with regard to their institutional leadership role in promoting 
sustainable development" [5]. Universities are also committed to playing the role of the central node in a dense network of relationships, configuring the European transnational system to orient it to the growth and sharing of knowledge, and the critical transmission of knowledge, with a view to quality and excellence [7-10].

Given the nature of their role and mission, Higher Education Institutions (HEIs) are depositories of culture and hold responsibility for the education of future generations; thus, they can directly contribute to sustainability culture diffusion, given their centrality in the socioeconomic context which they directly affect and within which they operate. In other words, HEIs represent a strategic resource for changing the lifestyle of people and the country they live in, by creating the conditions for active and aware citizenship, and then contributing to building resilient and sustainable societies [11-14].

In this scenario, sustainability becomes not only an evolutionary driver of organizations, but also assumes the role of a managerial director which, to be truly differential, must be supported by an adequate communication strategy. The choice that organizations make in communicating their sustainability efforts, and therefore their active role in sustainable development, should only intervene after a review of the activated processes and the activities implemented in a sustainable key [15].

Universities adopting SD principles orient their values, government, and processes along two axes:

1. they play a key role in elaborating and disseminating the sustainability theme;

2. they are able to efficiently transpose general principles into practice through strong commitment and transparent policies.

Regarding the first item, the universities are capable of collecting the sustainability needs that derive from civil society and other institutions and to translate them into research topics and educational programs. In this way, universities can amplify the diffusion of sustainability culture, integrating the concept of sustainable development (SD) into the research, organization, and education of the next generation of decision-makers [16]. In line with this point of view, the current practices of interdisciplinarity and of incorporating the environmental, economic, and social dimensions of sustainable development into academic programs and research networks are accelerating the shift towards the sustainability paradigm [17-20].

With reference to the second aspect, in recent decades universities in Italy and abroad have taken a path of change in which their traditional core activities of training and research find in the long-term vision increasing inspiration in the logic of SD [20]; this is even more so when coordinated with the recent 'Third Mission' processes, aimed at enhancing the ability to produce public engagement, value for companies, institutions, and professionals knowledgeable about the territory [21,22]. In this way, these organizations act to create dialogues and spaces for collaboration with different social actors, promoting several themes without being swayed by specific interests. Finally, universities use their expertise, capabilities, and leadership to encourage other stakeholders to adopt more sustainable policies and practices.

The second point of view becomes stronger as soon as the value of the United Nations Sustainable Development Goals (SDGs) (UN, 2015) $[23,24]$ becomes a qualifying feature of the organizational structure of all areas of competence of universities, inspiring their medium-to-long-term strategic planning. "Universities, in particular, are essential in the context of the SDGs because they can both equip the next generation with skills, knowledge, and understanding to address sustainability challenges and opportunities, and perform research that drives innovation and advances the sustainable development agenda" [24] (p. 129).

This has already been pointed out through the strategic planning processes in the universities' institutional activities, which become reorganized around the three pillars of Training, Research, and Third Mission. In particular, Agenda 2030 has inspired an integrated approach to strategic planning and social reporting, allowing universities to determine the effects of government action in socioeconomic and environmental terms. Universities' strategic plans tend to promote the principle of sustainability in their processes, functions, and activities, including actions aimed at promoting responsible 
lifestyles; improving the quality of life on the university campus; promoting systematic dialogue with stakeholders in and beyond the territory; cultural growth and sustainable economic progress of society; and supporting cohesion and social inclusion. With the adoption of an organizational and management model designed for this purpose and oriented towards actively involving the community, the university, and the territory [25], medium-long-term planning documents could be integrated by voluntary reporting tools-such as Social Reports and Sustainability Reporting-in response to stakeholders' demands and to legitimize their business strategies [26-29]. In doing so, Strategic Plans and Social and Sustainability Reports represent fundamental institutional communication tools for universities aiming to endorse the SDGs publicly and with specific declarations.

Despite the centrality of the topic, the literature has mainly focused on the definitions of sustainability and sustainable development principles and on their diffusion within universities. Universities usually seem to focus their attention on sustainability in the education of future decision makers (through the redefinition of curricula and research programs), in the operational management of university infrastructure (for example through the restructuring of the campus life in a "green" perspective), and in the adoption of sustainability reporting [11,30-34]. In particular, some Authors, while recognizing the complexity and multidimensionality of the theme and highlighting a growing efforts of HEIs to include sustainability in their activities, have underlined that in their initiatives such institutions often lack a holistic vision of sustainability [12,35].

Furthermore, from a methodological point of view, the most commonly recurring approaches are based on individual case studies, exploratory investigations aimed at understanding the motivations of key actors in HEIs to engage with the topic, and content analysis aimed at identifying the prevalently widespread SD categories between universities [1,6,14,35-37].

In this scenario, we follow the approach of Findler et al. (2019) [38,39] according to which the adoption of a holistic perspective to SD cannot be separated from a quali-quantitative analysis of the narratives used by HEIs to transpose the sustainability principles into their institutional documents. Only by reading and analyzing the documents of an organization is it possible to understand how much a principle has found concrete application and, therefore, has conditioned and oriented the decision-making processes of the organization itself.

In light of this introduction, the research aims to evaluate the degree of transposition of sustainability and sustainable development principles into the Italian university system. To this end, we here propose a possible reading of the institutional declarations using strategic plans and sustainability reports published by Italian universities. In our opinion, official communications represent cultural artifacts; they highlight the commitment to sustainability and efforts of these institutions, which are aimed at aligning their own internal processes with the expectations of stakeholders. For this reason, university communications could lead towards a shift of paradigm that relies on a new balance between the business, environment, and social spheres.

In particular, coherently with the aim of the research, we conducted an exploratory study on Universities' institutional declarations (SRs and SPs) available online, to verify the transposition of the Agenda 2030 SDGs into the Italian university system.

After a brief reconstruction of the institutional scenario, described by the Sustainability and Sustainable Development concepts, this article presents the role played by Italian universities. Finally, we give the findings of our analysis and main conclusions, including the limitations of the study and future development of the research.

\section{A Brief Reconstruction of the Institutional Scenario: Towards Agenda 2030}

As widely debated in the literature, the sustainability concept is associated with environmental and socioeconomic issues for future generations, and gained significant popularity with the Brundtland Report in 1987 (World Commission on Environment and Development, 1987), where the term 'Sustainable Development' first emerged. The report described it as "development that meets the needs of the present generations without compromising the ability of the future generations to meet their 
own needs" [40] (p. 284). In other words, SD found its main driver in 'solidarity' involving present-day actors and future generations in a vision structurally rooted in the general concept of sustainability.

The sustainability literature initially focused on environmental issues [41-44]; later, scholars highlighted the importance of balancing traditional sustainability-meaning environmental issues - with other dimensions, particularly the economic and social dimensions [34], as well as their interconnections through a holistic perspective [44]. A larger vision of SD thus led actors to deal with political, social, and economic themes as a whole.

The major socioeconomic popularity of the sustainable development concept is related to the triple bottom line framework, which links the businesses performance of an organization to three development lines: economic, social, and environmental [45], which is "a model that presently dominates the political and to some extent the academic debate on sustainable development" [46] (p. 131).

United Nations has provided the most recent interpretations of sustainable development (2015) in the form of the Millennium Development Goals (from 2000 to 2015), with its seventeen Global Goals and 169 targets for sustainability development, and now with Agenda 2030, a global and inclusive institutional framework for all types of organizations in a global society.

Agenda 2030 is an action plan that is determined to take the transformative steps needed to shift the world onto a sustainable path [47]. This is possible if the value and inspirational force of the SDGs manage to orient the behavior of individuals and organizations. Indeed, through the SD objectives and targets of Agenda 2030, the United Nations has indicated the problem's size and the urgency needed to set up brand new development models and trajectories. These objectives, to be reached by 2030, must translate into paths of change that are implemented on multiple levels in all areas of political action, society, and economy, in line with Agenda 2030's six dimensions of, as described by former UN Secretary-General Ban Ki-Moon: “dignity, people, planet, prosperity, justice and partnership" [43].

Now more than ever, the challenges faced by complex, polycentric, and multi-stakeholder organizations such as universities and HEIs in general, require reacquaintance with management objectives and conduct in the light of SD. Universities in Italy and abroad are integrating sustainability principles into their vision and mission, and SD in their practices, including education, research, community outreach, operations, assessment and reporting, collaborations and partnerships [17,24], as well as into institutional policies (such as organizational well-being, employee empowerment, social inclusion, and environmental sustainability) [48-50]. These actors are called to implement the guidelines of Agenda 2030, to plan and adopt models and mechanisms of governance that can consciously strategically orient the organization as a whole, in all dimensions, inspiring their actions.

First of all, this condition finds concrete form within universities and, in particular, in the behavior of human resources at all organizational levels: from teaching staff to technical and administrative levels, from management to students.

At the same time, universities can contribute to defining, with political and institutional bodies, the boundaries of an ideal space for discussion and 'virtuous' interaction on the sustainability theme, in all possible configurations, participating in defining the 'rules of the game' with other players. In other words, universities can become active actors in the political-institutional process that traces the trajectory of sustainable social development, helping to define the framework of action-and even more so, when in a network with other social actors.

\section{Sustainable Development in Italian Universities: From Strategic Planning to Sustainability Reporting}

In recent years, the Italian university system has experienced profound changes in the regulatory framework, which has increased the managerial autonomy of each university. From a competitive perspective, the regulatory framework requires more transparency from universities on their processes and objectives. Universities must thus declare in their strategic plan their achievable and tangible objectives; their current or available resources; and structured processes focused on clear activities with 
a view to continuous enhancement to ensure the efficiency, effectiveness, and sustainable administrative action [51-53].

The provisions of the regulatory framework arise from the requests of stakeholders in the shared socioeconomic scenario; they urge university management to follow the principles of sustainability, evaluating the effects in terms of sustainable development.

From a reputational perspective, these requirements produce socially valuable effects for universities, which can project their institutional vision and mission; this then affects university policy. These effects are amplified further by the central role played by universities in sustainable development in all its dimensions, and by the initiatives undertaken for this purpose: from the Education for Sustainable Development policy to supporting partnerships working in research and other policy fields on campus $[37,53,54]$.

For this reason, for many universities around the world, sustainability is no longer just one of the possible approaches available, but is now the single necessary and responsible development strategy [55].

In this scenario, the strategic axes of Agenda 2030 take on relevance:

- SDGs become key pillars in universities' strategic planning;

- the strategic planning of Italian universities must be formulated consistently with the Sustainable Development Goals of Agenda 2030, adopting as a starting point a clear "vision of how things might be changed for the better, and design or strategy for moving towards that vision" [53];

- Universities, which are at the forefront of adopting SDGs in their operations, need to deploy planning processes to achieve their vision;

- Italian universities need to plan for participation in the SDGs now, focusing on different axes such as education, research, community engagement (outreach), and operations as the main areas of development, linking them to a wide range of elements like infrastructure, competence, capacity building, among others;

- Strategic planning in accordance with the Agenda 2030 and SDG axes, linked to detailed and concrete action plans, could be considered a key explanatory variable for institutional commitment to sustainability.

Several Italian universities have gone beyond the regulatory requirements in drawing up their strategic plans. After determining the extent to which HEIs' activity (from the typical teaching and research to the "third mission") involves a plurality of stakeholders, these organizations have activated a communication process that reports performances with economic, social, and environmental dimensions. In particular, with a view to transparency and giving information to institutional and noninstitutional actors operating in the same territory, several Italian universities have decided to report their performance with the use of monitoring tools and voluntary reporting. The first document of this type is the Social Report, an effective tool for dialogue with internal and external stakeholders. In recent years, some universities have started to draft Sustainability Reports (Report on UN Sustainable Development Goals), which is intended to trace the universities' contribution to the achievement of each of the 17 SDGs of Agenda 2030. "During the past decade, companies worldwide have adopted sustainability reporting (SR) in response to stakeholders' demands and in an effort to legitimize their business strategies" [28] (p. 144).

Universities are moving in the direction of sustainability reporting, applying the standards of the Global Reporting Initiative (GRI), an independent international organization that helps businesses and governments worldwide to understand and communicate their impact on critical sustainability issues (www.globalreporting.org). Through sustainability reporting, universities voluntarily choose to communicate their efforts on these issues, legitimizing their efforts and progress. In this way, universities certify their attention on the territory and trace the impacts made by their actions on sustainable development. This transparency leads to better decision-making processes, which helps build and maintain trust in relationships. 
On one hand, their reporting activities are useful in communicating sustainability performance and the impacts on internal and external stakeholders, in terms of the economic, environmental, and social aspects, for setting goals, and managing change effectively. On the other hand, reporting is strengthening universities' commitments and, at the same time, will trace the results of the actions they have undertaken to implement Sustainable Development.

Although only a few Italian universities have adopted sustainability reporting, the Italian university system participated in 2015 in the creation of the first network for sustainable development-RUS, the Italian university network for sustainable development, by the Conference of Italian University Rectors. This means that, while the pillars of the SDGs (already implemented by many universities in Italy and abroad) have been contributing to configuring the current institutional framework, about sixty university communities have settled on a network configuration. This represents the first initiative of coordination and sharing among Italian universities engaged in the issues of environmental sustainability and social responsibility [56]. Today, this network is the place to conceive, share, and experiment with sustainability strategies and practices. This orientation was already widely confirmed in the strategic objectives of the Lisbon European Council, in March 2000, conferred on the European Union: to develop a knowledge-based economy, more competitive and dynamic, capable of achieving sustainable growth with better work conditions and greater social cohesion.

The network further strengthens the key role that universities assume, not only in the academic debate, but also in political and institutional debates on sustainability and the strategies and actions to be undertaken to cocreate shared value [57].

On the basis of the previous reflections, we adopt the point of view of the double logical level on which RUS plays to the theme of sustainability:

1. On the socioeconomic level, universities play a key role in the process of developing and disseminating sustainability as a knowledge-intensive process [58,59]. They are ideally placed within an interdisciplinary and multi-actor space (social, economic, political, and institutional) that contributes to defining the 'rules of the game';

2. Universities have the necessity and opportunity to recognize themselves as sustainable organizations [57,60], internalizing the principle of sustainability on all levels of the organization, operating responsibly with actions focused on economic, environmental, and social gains [53].

The commitment of RUS is contributing to the creation of a partnership between Italian universities that stimulates a transdisciplinary scientific debate while, at the same time, urging and supporting the adoption of sustainable behaviors. This conduct confirms the twofold interpretation of the university-sustainability relationship.

The real impact of the universities' participation in the network is that they are assessed in terms of the pervasive sustainable development objectives, from the adoption of the strategic vision (in training, research, and "Third Mission") to the use of monitoring and evaluation tools.

In the same way, strategic plans and sustainability reports should be structured according to the same strategic axes, allowing timely comparison between actions and performance.

\section{Research Design}

Starting from the assumption that the sustainable development vision pervades every area of universities' interests, this topic involves radically rethinking curricula, pedagogy, and institutional culture in terms of sustainable development. In the last decade, these organizations have begun to adopt a wider vision on sustainability, clearly characterizing their mission, their training, and research policies and objectives, both individually and collaboratively [32-34,61-63]. This means that strategic planning and sustainability reporting is tracing the evolutionary path of educational initiatives, research, and partnerships with stakeholders.

Working with this theme, the present article develops exploratory research on universities' institutional declaration (sustainability reports and strategic plans) available online, which aim at 
evaluating the transposition of the Agenda 2030 SDGs into the Italian university system. In our opinion, the widespread and clear presence of these objectives in the official declarations represents a prerequisite for greater communication effectiveness, contributing to the construction of a sustainable reputation and to a social legitimization of universities.

From a methodological point of view, we have conducted a content analysis to analyze text data through a systematic classification process, involving coding and identifying themes $[8,64,65]$, in order to produce a qualitative content analysis of institutional communication documents $[66,67]$.

\subsection{Sample and Data Collection}

The starting point of this work is the evaluation of the degree of transposition of the Agenda 2030 SDGs into the Italian university system.

We proceed with a qualitative analysis of the contents of the SRs and SPs available online of a sample of Italian universities. The analysis stage uses MAXQDA 2020, as one of the most widespread tools in the field of qualitative data analysis.

To determine the sample, we began with Italian universities that participated at least in one of the two annual world assessments measuring the sustainability performance of universities that of the Times Higher Education (THE) Impact Rankings and the UI GreenMetric World University Ranking.

In particular, since 2019, the THE Impact Rankings have evaluated the performances of global universities in delivering the United Nations' Sustainable Development Goals; they are the only global performance tables to do so. They employ calibrated indicators to provide comprehensive and balanced comparisons across the three broad areas of research, outreach, and stewardship.

The UI GreenMetric, an initiative of Universitas Indonesia (the University of Indonesia) that launched in 2010, monitors current policies and related actions aimed at realizing green campuses and sustainability in universities all over the world; this metric has six dimensions: Setting and Infrastructure, Energy and Climate Change, Waste, Water, Transportation, and Education and Research.

The sample consists of Italian state universities that fulfil all these three conditions:

1. they appear in one of the two sustainability performance rankings;

2. their Sustainability Reports and Strategic Plans are available online;

3. they are members of RUS.

The sample is described in Table 1.

Table 1. Sample of research.

\begin{tabular}{ccc}
\hline Institution & Size & Geographical Location \\
\hline Alma Mater Studiorum, Bologna & over 40,000 students & Northern Italy \\
University of Turin & over 40,000 students & Northern Italy \\
Ca' Foscari University of Venice & 10,000 to 200,000 students & Northeastern Italy \\
University of Milano, Bicocca & 10,000 to 200,000 students & Northern Italy \\
Polytechnic of Turin & polytechnic & Northern Italy \\
University of L'Aquila & 10,000 to 200,000 students & Central Italy \\
University of Genova & 20,000 to 40,000 students & Northwestern Italy \\
University of Bari Aldo Moro & over 40,000 students & Southern Italy \\
University of Perugia & 20,000 to 40,000 students & Central Italy \\
University of Padova & over 40,000 students & Northern Italy \\
La Sapienza University of Rome & over 40,000 students & Central Italy \\
IUAV University of Venice & polytechnic & Northeastern Italy \\
University of Parma & 20,000 to 40,000 students & Northern Italy \\
\hline
\end{tabular}

In line with the role of HEIs, and to understand the degree to which sustainability can be transposed into the Italian university system, this work explores institutional declarations based on the four pillars of Agenda 2030 and its areas of interest. 
To define the scope of this study, we have summarized the Guide to Universities, Higher Education Institutions, and the Academic Sector produced by Sustainable Development Solutions Network (SDSN) [61]. Starting with the assumption that education and research are explicitly linked to a large number of the SDGs, and that universities play a key role in addressing them, the SDSN underlines that the contribution of universities to the SDGs is broader: these institutions can in fact support the implementation of the SDG framework as a whole.

We have summarized the main areas of university contribution to the SDGs, as proposed by the SDSN, and have adopted a revision of them. In particular, after defining the research analysis units (SR and SP), we identified the categories of analysis (the pillars of Agenda 2030) and the classification units for use in investigating the documents (Table 2).

Table 2. Pillars of Agenda 2030 as analysis categories.

\begin{tabular}{|c|c|c|}
\hline $\begin{array}{l}\text { PILLARS } \\
\text { (Categories of Analysis) }\end{array}$ & $\begin{array}{l}\text { SDG Area of Interest } \\
\text { (Classification Units) }\end{array}$ & Descriptions \\
\hline \multirow{9}{*}{$\begin{array}{l}\text { 1. LEARNING AND } \\
\text { TEACHING }\end{array}$} & $\begin{array}{l}\text { 1.1_Education for Sustainable } \\
\text { Development (ESD) }\end{array}$ & $\begin{array}{l}\text { Developing relevant resources and tools (introducing } \\
\text { SDGs and the principles of ESD into undergraduate and } \\
\text { graduate courses, as well as graduate research training). }\end{array}$ \\
\hline & 1.2_Networking for Education & $\begin{array}{l}\text { Courses built around real-world collaborative projects } \\
\text { for change. Students have the opportunity to act and } \\
\text { reflect iteratively, while teachers can cooperate with } \\
\text { other actors to stimulate adaptive capacity. }\end{array}$ \\
\hline & $\begin{array}{l}\text { 1.3_Mobilisation of young people } \\
\text { in activities }\end{array}$ & $\begin{array}{l}\text { Young people are key drivers of SD. Universities can } \\
\text { harness their direct access to a large number of young } \\
\text { people and drive them to contribute to all the SDGs, } \\
\text { stimulating their creativity and encouraging them to } \\
\text { participate in different projects. }\end{array}$ \\
\hline & $\begin{array}{l}\text { 1.4_Inclusive and equitable } \\
\text { quality education }\end{array}$ & $\begin{array}{l}\text { Promoting the knowledge, skills, and values needed to } \\
\text { contribute to the development of civil society, ensuring } \\
\text { equal access for all to affordable and quality technical, } \\
\text { vocational, and tertiary education. }\end{array}$ \\
\hline & $\begin{array}{l}\text { 1.5_Capacity building } \\
\text { for education }\end{array}$ & $\begin{array}{l}\text { Training in the SDGs and ESD for all curriculum } \\
\text { developers, course coordinators, and lecturers, and } \\
\text { capacity building courses for external stakeholders. }\end{array}$ \\
\hline & $\begin{array}{l}\text { 1.6_Capacity building of students } \\
\text { and professionals }\end{array}$ & $\begin{array}{l}\text { Developing partnerships with other countries through } \\
\text { international campuses, academic exchange programs, } \\
\text { and partnerships with universities, which can help } \\
\text { support capacity building among students and } \\
\text { professionals for the SDGs. }\end{array}$ \\
\hline & $\begin{array}{l}\text { 1.7_Training for jobs that } \\
\text { implement SDGs }\end{array}$ & $\begin{array}{l}\text { Contributing to all SDGs by ensuring training students } \\
\text { for the jobs that are needed to implement SDGs. }\end{array}$ \\
\hline & $\begin{array}{l}2.1 \_ \text {Research for SD } \\
\text { (or relating to SDGs) }\end{array}$ & $\begin{array}{l}\text { Support for research into the SDGs being internalized } \\
\text { within the policies and culture of the university. }\end{array}$ \\
\hline & 2.2_Capacity building for research & $\begin{array}{l}\text { Partnerships and exchange programs with universities in } \\
\text { developing countries around areas of relevance to the } \\
\text { SDGs; encouraging joint research projects on the SDGs or } \\
\text { facilitating knowledge exchange with and } \\
\text { among communities. }\end{array}$ \\
\hline
\end{tabular}


Table 2. Cont.

\begin{tabular}{|c|c|c|}
\hline \multirow{6}{*}{ 2. RESEARCH } & $\begin{array}{l}\text { 2.3_Mobility and } \\
\text { internationalization for research }\end{array}$ & $\begin{array}{c}\text { Supporting the international mobility of researchers to } \\
\text { allow them to engage in the efforts of the global research } \\
\text { community to support the SDGs (such as international } \\
\text { assessments and syntheses of the current state } \\
\text { of knowledge). }\end{array}$ \\
\hline & $\begin{array}{l}\text { 2.4_Interdisciplinary and } \\
\text { transdisciplinary research }\end{array}$ & $\begin{array}{l}\text { Adoption of different research approaches (traditional } \\
\text { disciplinary approaches, in particular, fundamental } \\
\text { empirical and applied or pragmatic research). }\end{array}$ \\
\hline & 2.5_Networking for research & $\begin{array}{l}\text { Networking to prospect for 'innovative solutions' to help } \\
\text { governments, businesses, and civil society in practicing } \\
\text { sustainable development. }\end{array}$ \\
\hline & $\begin{array}{l}\text { 2.6_Support and incubate } \\
\text { innovation for social development }\end{array}$ & $\begin{array}{l}\text { Universities, as centers of innovation, invention, and } \\
\text { discovery, can lead the development of social and } \\
\text { technological innovations and solutions across SDG } \\
\text { challenges, expanding their role as hubs of innovation. }\end{array}$ \\
\hline & $\begin{array}{l}\text { 2.7_Support national and local } \\
\text { implementation of } \\
\text { social development }\end{array}$ & $\begin{array}{c}\text { Developing collaborative relationships with industry, } \\
\text { government, communities, private sector, and } \\
\text { nongovernmental organizations around specific } \\
\text { SDG challenges. }\end{array}$ \\
\hline & $\begin{array}{l}\text { 2.8_Scholarships and funding } \\
\text { opportunities for research }\end{array}$ & $\begin{array}{l}\text { Promoting innovative research through national research } \\
\text { funding specifically for interdisciplinary and } \\
\text { SDG-related research. }\end{array}$ \\
\hline \multirow{4}{*}{$\begin{array}{l}\text { 3. OPERATIONS AND } \\
\text { GOVERNANCE }\end{array}$} & $\begin{array}{l}\text { 3.1_Align governance structure } \\
\text { with SDGs }\end{array}$ & \multirow{2}{*}{$\begin{array}{l}\text { Implementation of the SDGs through governance } \\
\text { structures and operational policies and decisions, such as } \\
\text { those relating to employment, finance, facilities, } \\
\text { procurement, human resources, and student administration. }\end{array}$} \\
\hline & $\begin{array}{l}\text { 3.2_Operational policies } \\
\text { and decisions }\end{array}$ & \\
\hline & $\begin{array}{l}\text { 3.3_Supporting environment, } \\
\text { social, and governance (ESD) } \\
\text { principles through } \\
\text { investment policies }\end{array}$ & $\begin{array}{l}\text { Universities formally reporting their investments and } \\
\text { their sizes in order to promote environment, social, and } \\
\text { governance (ESG) principles. }\end{array}$ \\
\hline & $\begin{array}{l}\text { 3.4_Corporate social responsibility } \\
\text { and sustainable campus activities }\end{array}$ & $\begin{array}{c}\text { Campuses can generate an impact on every one of the } \\
\text { SDGs. It is possible to observe a significant overlap } \\
\text { between the SDG agenda and the CSR and sustainable } \\
\text { campus activities. }\end{array}$ \\
\hline \multirow{5}{*}{$\begin{array}{l}\text { 4. EXTERNAL } \\
\text { LEADERSHIP }\end{array}$} & $\begin{array}{l}\text { 4.1_Strenghtening public } \\
\text { engagement in addressing } \\
\text { the SDGs }\end{array}$ & $\begin{array}{l}\text { Supporting public engagement and participation in } \\
\text { addressing the SDGs through the organization of public } \\
\text { lectures, community events, forums, and interactive } \\
\text { workshops to raise awareness of the SDGs. }\end{array}$ \\
\hline & $\begin{array}{l}\text { 4.2_Cross-sectoral dialogue and } \\
\text { action on SDG implementation }\end{array}$ & $\begin{array}{l}\text { Facilitating cross-sectoral dialogue, collaboration, and } \\
\text { partnerships on solutions to addressing the challenges of } \\
\text { specific SDGs. }\end{array}$ \\
\hline & $\begin{array}{l}\text { 4.3_Lead role in policy } \\
\text { development/advocacy for SD }\end{array}$ & $\begin{array}{l}\text { Policy development and advocacy for SD, in } \\
\text { collaboration with policymakers, to propose solutions } \\
\text { and to assist in policy evaluation. }\end{array}$ \\
\hline & $\begin{array}{l}\text { 4.4_Demostrating the importance } \\
\text { of universities for sector role } \\
\text { in SDGs }\end{array}$ & $\begin{array}{l}\text { Ensuring the sector is coherently represented at every } \\
\text { discussion table, building networks with other } \\
\text { universities, and seeking opportunities to develop } \\
\text { guidance and tools to support the national and regional } \\
\text { implementation of the SDGs. }\end{array}$ \\
\hline & $\begin{array}{l}\text { 4.5_Demonstrate the university } \\
\text { sector's commitment to SDGs }\end{array}$ & $\begin{array}{l}\text { Making the SDGs a prominent part of university } \\
\text { marketing, creating networks to promote SDGs, and } \\
\text { participating in international rankings, so as to } \\
\text { demonstrate and communicate their awareness of } \\
\text { SD principles. }\end{array}$ \\
\hline
\end{tabular}

In particular:

1. The first pillar of Learning and Teaching refers to the key role of universities in providing inclusive and equitable quality education and promoting lifelong learning opportunities for their students. 
These institutions are presently involved in professional educational paths, and at the same time are called to guarantee a connection between students and their professional life, building social and emotional skills.

2. The second pillar, Research, underlines the universities' critical role in providing the necessary knowledge, evidence-based solutions and innovations to underpin and support the implementation of the SDGs, through a range of research approaches (disciplinary, interdisciplinary, transdisciplinary, and sustainability science); building capacity for sustainable development research; partnerships with other institutions, public and private, local and national, to sustain country development; resources to sustain diversity in research, funding innovative research and supporting companies to adopt innovations for SDGs.

3. The third pillar of Operations and Governance is focused on the aligning university governance structures and operational policies with the aims of the SDGs. It is opportune to point out the significant overlap between the SDG Agenda, corporate social responsibility, and sustainable campus activities that many universities are engaged in. These actions are strongly linked with governance structures (e.g., the establishment of Green Offices and Sustainability Commissions) and operational policies and decisions relating to employment, finance, campus services, support services, procurement, human resources, and student administration.

4. The fourth pillar, External Leadership, aims to underline the key role that universities can play within communities, guiding and supporting local, national, and international response to the SDGs. The journey to sustainable development is based on the involvement of civil society, the business sector, and the scientific and academic communities. The collaboration between these different actors needs significant leadership and the capacity to understand the socioeconomic scenario. Universities have a central position in civil society, which makes them potential leaders in SDG-oriented projects.

\section{Findings}

Consistent with the research objective, the documents selected for the content analysis are the most recent SRs and SPs drawn up by a sample of Italian universities after the publication of Agenda 2030. It is necessary to underline the different nature of these documents: SRs are accountability and reporting documents, while SPs are programmatic documents. The analysis of SRs thus allows us to detect the areas of interest in which the greatest number of initiatives have been undertaken, while examining the SPs allows us to point out the approaches that universities want to adopt and the areas of interest in which they intend to invest resources. It should be noted that there are no contributions that investigated narratives adopted by HEIs in their institutional documents (SRs and SPs). Other Authors have conducted a content analysis aimed at identifying the prevalently widespread SD categories among universities [26], exclusively focusing the attention on the dissemination of voluntary disclosure in the university system, not investigating the actual implementation of the principles of the SD in formal decisions contained in the SPs.

Before conducting the content analysis on SRs and SPs narratives, we analyzed the recursion of some keywords in the selected texts to confirm their presence in the institutional documents. Keywords relating to sustainability in a broad sense contributed to define the three conditions chosen for the identification of the investigated sample. In particular, it should be noted that the keyword "Ranking" refers to the two metrics "THE Impact Rankings" and "UI GreenMetric".

Table 3 shows the frequency of selected Italian keywords in analyzed documentation. The document analysis shows the indisputable recursion of the sustainability concept, evidently elevated to a transversal dimension in all strategic areas. We can observe explicit reference to the SDGs in 18 out of 26 documents. 
Table 3. Keywords in Sustainability Reports (SR) and Strategic Plans (SP) by frequency.

\begin{tabular}{ccccc}
\hline Keyword & Freq. & $\begin{array}{c}\text { No. } \\
\text { Documents }\end{array}$ & SR & SP \\
\hline Sostenibilità & 1619 & 26 & 1020 & 575 \\
Sviluppo Sostenibile & 346 & 24 & 266 & 79 \\
Sostenibilità Ambientale & 166 & 19 & 126 & 35 \\
Ranking & 152 & 22 & 74 & 77 \\
RUS (Rete delle Università per lo Sviluppo & 138 & 16 & 121 & 17 \\
Sostenibile) & 107 & 18 & 103 & 4 \\
SDGs (Social Development Goals) & 103 & 3 & 101 & 2 \\
Bilancio ambientale & 100 & 10 & 46 & 54 \\
Sostenibilità economica & 51 & 11 & 38 & 12 \\
Sostenibilità sociale & 50 & 5 & 50 & 0 \\
GRI (Global Reporting Initiative) & 23 & 5 & 11 & 12 \\
Agenda 2030 & 16 & 8 & 12 & 4 \\
Bilancio sociale & & &
\end{tabular}

The codification phase involved two people. In line with the proposed reflections in the previous paragraph, after defining the research analysis units (SR and SP), we selected the categories of analysis and the classification units to codify the institutional documents (Table 2). In particular, in the preliminary phase of the research, we shared and normalized the codes to make the subsequent codification phase consistent. Then, following the content analysis methodology, a text coding phase was preliminarily performed. Here, the research group codified the selected text segments based on the variables (Table 2, column 2). Once the coding was complete, the tallied codes were divided by the number of coded segments in each context (classification units) to give the relative scores.

The authors set the total number to $100 \%$ and reported the absolute (n) and relative (n [\%]) amounts for each 'document group' (SRs and SPs), in proportion to the total number of coded segments for each pillar (Table 4). The frequency of each classification unit and of each category of analysis (pillar) were then taken to describe the degree to which sustainability was transposed into the documents.

Table 4. Distribution of coded segment for the category of analysis per SR and SP.

\begin{tabular}{cllllll}
\hline Coded Category (Pillars) & $\begin{array}{l}\text { Total } \\
\text { Freq. }\end{array}$ & $\begin{array}{l}\text { Freq. } \\
\text { (SR) }\end{array}$ & $\begin{array}{l}\text { Freq. } \\
\text { (SP) }\end{array}$ & $\%$ \\
\hline 1. Education and Learning & 348 & $19 \%$ & 159 & $17 \%$ & 189 & $21 \%$ \\
2. Research & 371 & $21 \%$ & 176 & $19 \%$ & 195 & $22 \%$ \\
3. Operations and Governance & 659 & $36 \%$ & 381 & $41 \%$ & 278 & $32 \%$ \\
4. External Leadership & 429 & $24 \%$ & 209 & $23 \%$ & 220 & $25 \%$ \\
\hline Number of coded segments & 1807 & $100 \%$ & 925 & $100 \%$ & 882 & $100 \%$ \\
\hline
\end{tabular}

The total number of coded segments was 1807 (925 in SRs and 882 in SPs).

The document analysis allows us to identify the areas of greatest interest for the investigated universities, in line with the four pillars that summarize the commitment of these organizations towards sustainable development, as enshrined in the seventeen objectives and related targets identified by Agenda 2030.

Table 4 shows that the pillar that most inspires universities' decisions, both in the reporting and programming phase, is "Operations and Governance" (36\%), while the area with the least sustainability transposition is the characteristic pillar in universities, namely Education and Learning (19\%).

The statements that were analyzed show the need to create adequate governance structures is a sine qua non condition for taking any action that seeks to carry out teaching and research-oriented towards sustainable development and concrete public engagement. Added to this, universities seem to be oriented towards urgent measures that transfer socially responsible conduct to stakeholders-for 
example, all the policies dealt with water consumption, rather than with careful waste management, car sharing, and others.

The sustainability transposition degree in the External Leadership pillar is very interesting ( $36 \%$ of coded segments in SRs and 32\% of coded segments in SPs), and the result confirms the universities' awareness of their guiding role on sustainability for other actors.

\subsection{Content Analysis of Sustainability Reports}

Content analysis of the SRs made it possible to identify the areas of greatest interest for the sample, in line with the four pillars that summarize the commitment of these organizations towards sustainable development, as enshrined in the seventeen objectives and related targets identified by Agenda 2030.

The figures below show the proportion of coded segments for each classification unit as a fraction of the total number of coded segments for each category of analysis (pillar) (Figure 1a-d). In the Education and Learning pillar, sustainability transposition is most represented in the education planning process for sustainable development (ESD), with $26.4 \%$ of the coded segments referring to this category. Universities consolidate the process of teaching quality enhancement, expanding and requalifying the range of training they offer with a view to sustainability and sustainable development, increasing the involvement of all disciplinary areas.

Despite the fact that other classification units show a lower degree of sustainability transposition (as measured by the number of coded segments for classified units), all show the universities' commitment to supporting sustainable development. Italian universities have begun their process of SDG implementation, ensuring their agility and ability to be ready for change, creating links with business and industry to monitor employer trends and skills requirements-for example, through business communities of practice. At the same time, they are enhancing opportunities for lifelong learning, such as executive education, online learning, and vocational training.

Regarding the second pillar, Research, the decisions relating to sustainability issues are developed within specific research projects (40.6\%) and technology transfer (15.4\%) conducted by departments and university centers; economic, social, and environmental sustainability issues are also studied with reference to the business world, through the activation of ad hoc networking processes (13\%).

In particular, the Research pillar analysis allows to evaluate the commitment of Italian universities to supporting the local and national implementation of SD $(10.9 \%)$ which is reflected in classification unit 4.3 in the external leadership pillar (lead role in policy development with 20 occurrences, or $8 \%$ ). Indeed, universities recognize the need for a direct commitment to organize collaborative initiatives for the dissemination of the principles of sustainable development on the political and socioeconomic levels. In this way, universities offer their professional profile, knowledge, and research to support policymakers in understanding the implications of different policy options and designing a new political scenario. Universities are often large entities with significant effects on the social, cultural, and environmental wellbeing of their campuses and communities. Universities can manage a network made up of employers, consumers, investors, and real estate holders; they coordinate staff, students, and other actors. Campuses are organized like small cities, creating international flows of people and goods, and supporting investments in infrastructure. Organizations are beginning to understand and identify the impacts of the SDGs within their operational sphere of influence.

In this scenario, universities' awareness of the impacts of their decisions and operations is shown by the results relating to the third pillar, Operations and Governance (the pillar with the greatest number of coded segments, then for degree of sustainability transposition). Their commitment is clear and is shown in particular by the degree of sustainability transposition in their governance structure $(25.5 \%)$ and in operational policies and decisions related to SDGs $(41.3 \%)$. 


\section{1.a Education and Teaching Pillar}

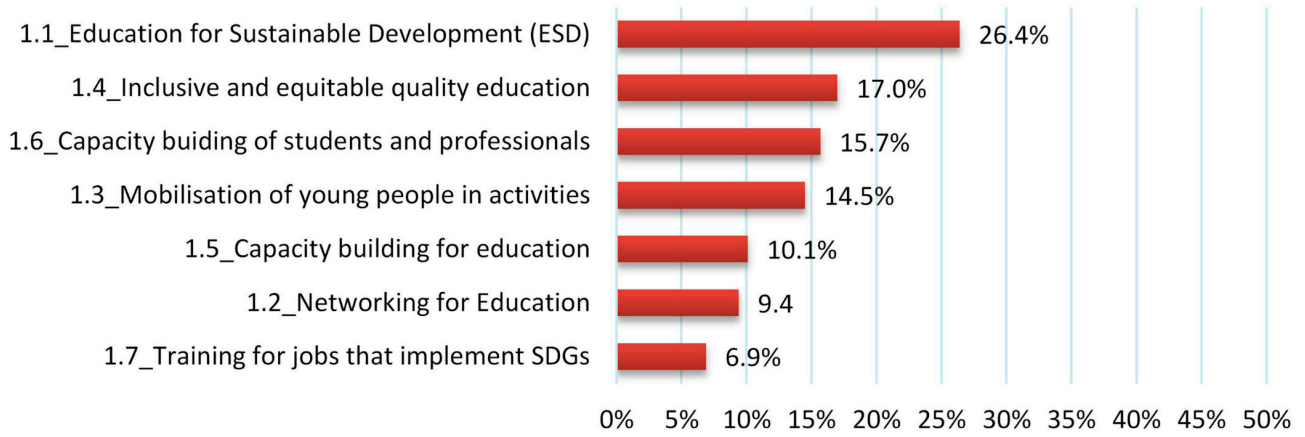

\section{1.b Research Pillar}

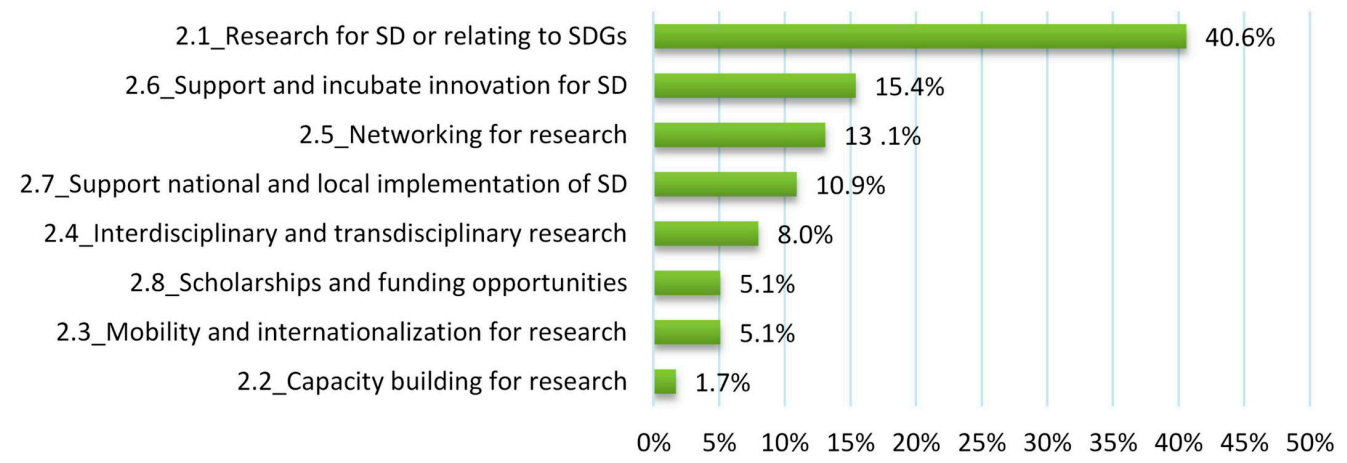

\section{1.c Operations and Governance Pillar}

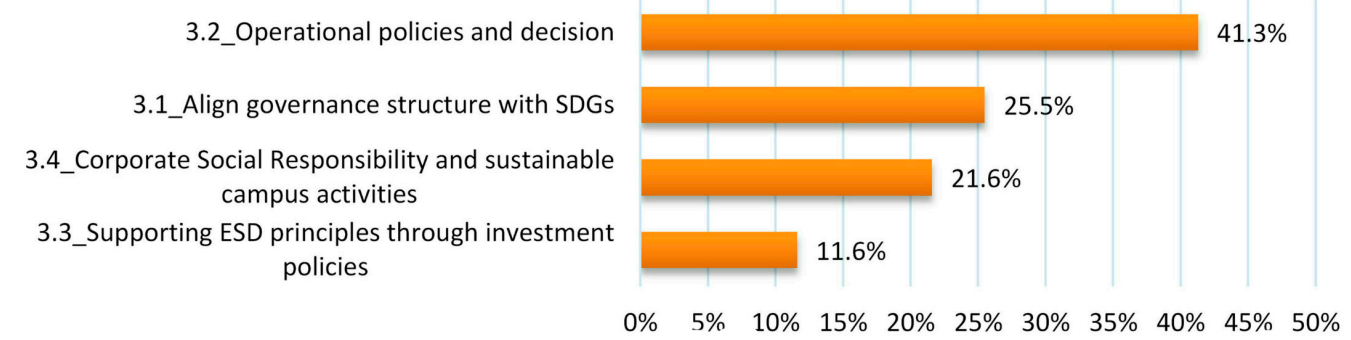

\section{1.d External Leadership Pillar}

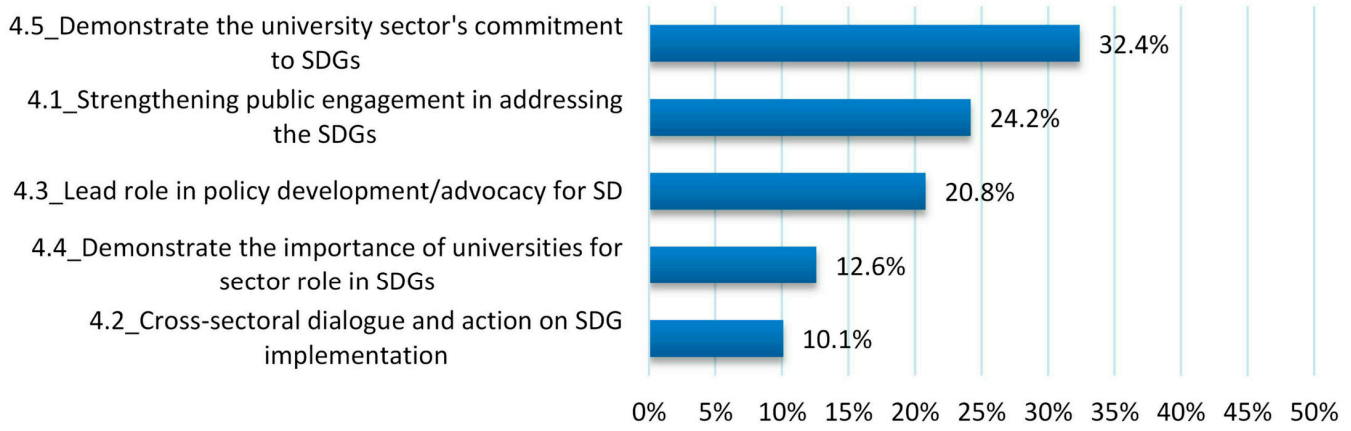

Figure 1. Coded segments for each pillar of the analysis in SRs. Source: Authors' elaboration. Note: The Figure shows the percentage of coded segments for each classification unit as a proportion of the total number of coded segments for each category of analysis (pillar) in Sustainability Reports of the sample. In particular: (a) shows the percentage of coded segments for each classification unit for Education and Teaching pillar; (b) shows the percentage of coded segments for each classification unit for Research pillar; (c) shows the percentage of coded segments for each classification unit for Operations and Governance pillar; (d) shows the percentage of coded segments for each classification unit for External Leadership pillar. 
Finally, the External leadership pillar aims to underline the key role of universities for SDGs expressed by the degree of sustainability transposition in each classification unit: 1 . as a leader in networking and partnership processes (25.5\%); and 2. working to support the implementation of the SDGs within the university (through teaching, research, and operations), and so demonstrating commitment and ensuring the sustainability disclosure in all debates (32.4\% and $12.6 \%)$. Many of these have significant prominence and influence in the public sphere and supporting policymaking (20.8\%). At the same time, the SDGs provide an opportunity to enhance this role. We can interpret the SP content analysis results with regard to the same pillar in this light.

\subsection{Content Analysis of the Strategic Plans}

The SP content analysis allowed us to outline the degree of sustainability transposition with respect to the objectives that universities wish to pursue in the near future, such as new initiatives or the consolidation of initiatives (Figure 2a-d). From a programmatic perspective, the analysis of the first pillar shows a strong interest in capacity building of students and professionals. Universities, through their links with domestic and international campuses and very diverse partnerships with other partners, aim to engage international students, develop free quality online courses on sustainable development, and provide SDG-related scholarships for students. It should be emphasized that these organizations also maintain a significant focus on promoting virtuous behaviors that mobilize and involve students directly.

With reference to the second pillar, Italian universities' commitment is focused on sustainable development in its various dimensions (environmental, economic, social, and technological) to create a new culture among young people. In addition to this, while a reduced focus on scholarships and funding opportunities for research emerged from the SRs (5.1\%), the SPs make evident a need to support and facilitate research through promoting and funding interdisciplinary and transdisciplinary work on the SDGs (12.7\%).

This aim arises from the need to address complex issues, typically linked to societal challenges, which have an interdisciplinary and transdisciplinary nature.

SPs analysis of the Operations and Governance pillar seems to overlap with the SR analysis of the same. Universities are presently committed to creating the conditions for all promoted actions in terms of sustainability and environmental development, to be carried out and consolidated within their organizations, largely managed through governance structures and operational policies and decisions. For this reason, classification units 3.2 and 3.1 have sustainability transposition degrees of $39.4 \%$ and $21.6 \%$, respectively.

"By addressing their impacts within each area of the SDGs through their internal policies and operations, universities can make a significant contribution to achieving the SDGs within their spheres of operation" [68] (p. 23).

As mentioned, a significant conceptual overlap is seen between the SDGs and the corporate social responsibility and sustainable campus activities that many universities are already deeply engaged in. This emerges from the results shown in Figure 2c.

Finally, the analysis of the last pillar (External Leadership) shows that unsurprisingly, from a programmatic point of view, the classification unit with the greatest degree of sustainability transposition is unit 4.1 (Strengthen public engagement in addressing the SDGs, with $30.2 \%$ of the coded segments) immediately followed by unit 4.5 (Demonstrate university sector's commitment to SDGs with $28.8 \%$ of coded segments). It is important to highlight another element that characterizes Italian universities today: the Third Mission. This dimension describes the numerous ways in which the activities and benefits of higher education and research can be addressed and shared with a wide, heterogeneous audience. These are modalities with cultural, popular, social, and educational value which are receiving great interest from Italian universities (e.g., community events to raise awareness of the SDGs, interactive workshops, debates on actions, solutions, innovations, and technologies, and suggestions of new ideas). 


\section{2.a Education and Teaching Pillar}

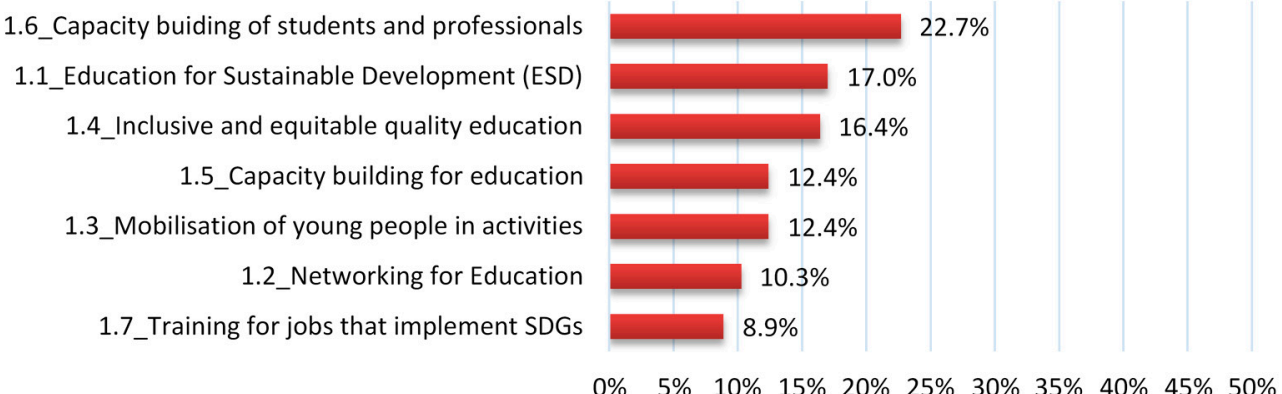

\section{2.b Research Pillar}

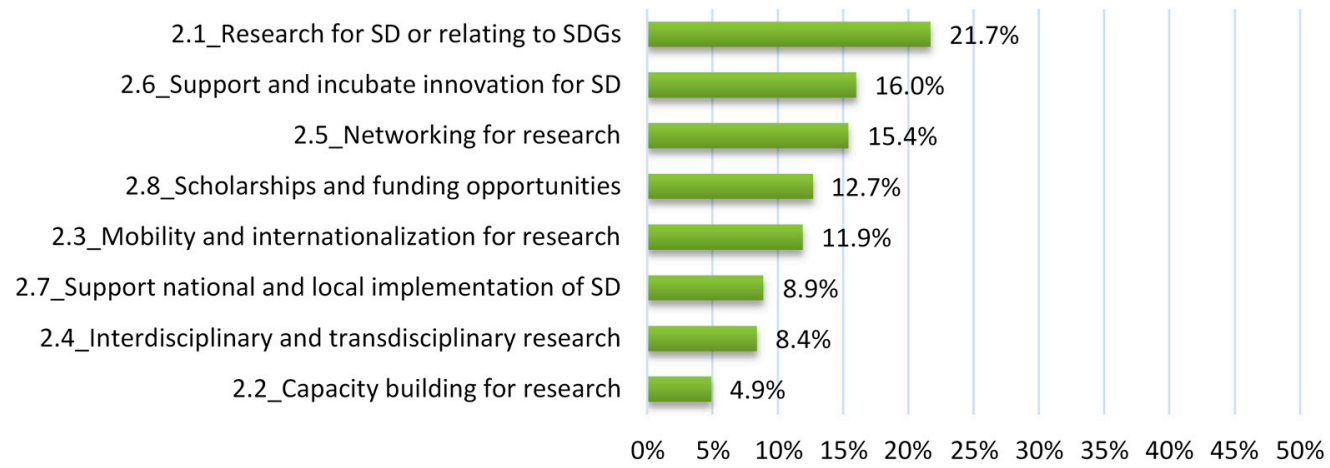

\section{2.c Operations and Governance Pillar}

3.2_Operational policies and decision

3.1_Align governance structure with SDGs

3.4_Corporate Social Responsibility and sustainable campus activities

3.3_Supporting ESD principles through investment policies

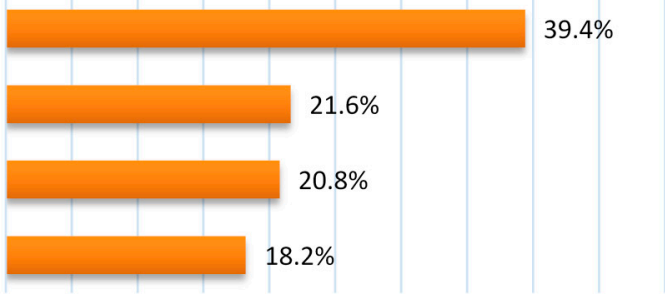

$\begin{array}{llllllllllll}0 \% & 5 \% & 10 \% & 15 \% & 20 \% & 25 \% & 30 \% & 35 \% & 40 \% & 45 \% & 50 \%\end{array}$

\section{2.d External Leadership Pillar}

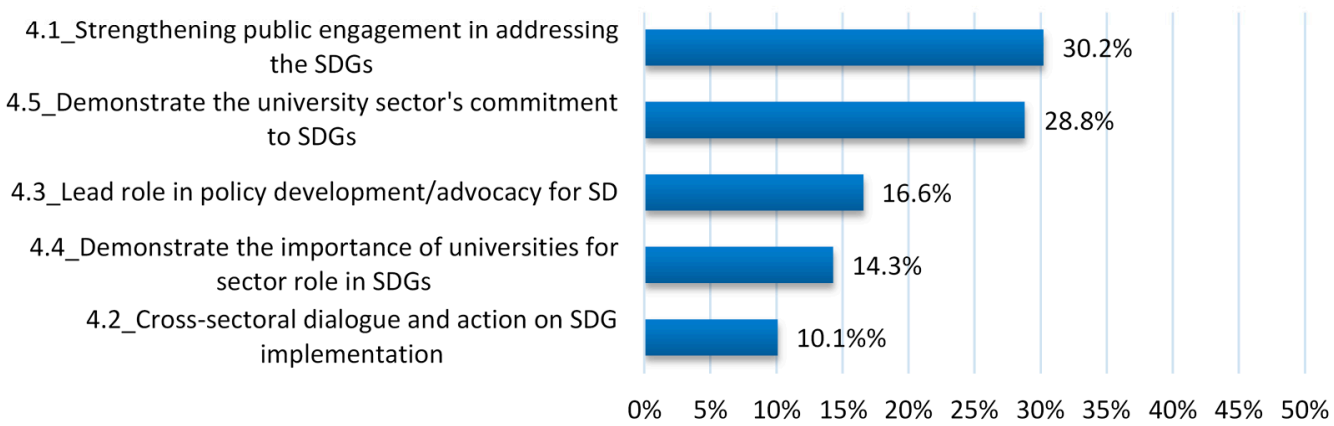

Figure 2. Coded segments for each pillar of analysis in SPs. Source: Authors' elaboration. Note: The Figure shows the percentage of coded segments for each classification unit as a proportion of the total number of coded segments for each category of analysis (pillar) in Strategic Plans of the sample. In particular: (a) shows the percentage of coded segments for each classification unit for Education and Teaching pillar; (b) shows the percentage of coded segments for each classification unit for Research pillar; (c) shows the percentage of coded segments for each classification unit for Operations and Governance pillar; (d) shows the percentage of coded segments for each classification unit for External Leadership pillar. 
In this scenario, universities implement strategies to involve the public in community spaces, real or virtual, thus promoting sustainability culture. This requires that universities activate communication channels with communities and partners and raise public awareness.

\section{Conclusions}

Our document analysis presents the reader with a reconstruction of the initiatives inspired by sustainability and the sustainable development principles of a sample of Italian universities. The results demonstrate on the part of the universities a considerable awareness of and commitment to the key role played by sociopolitical and economic levels for the diffusion and penetration of the Agenda 2030 SDGs within the university system and within civil society.

Starting from this conclusion, we should underline that the pursuit of sustainable development in universities is not just a political issue; strategies and declarations of intent must be followed by real initiatives. For this reason, universities must plan and carry out real projects for sustainable development, to link intentions with effective actions to implement this strategic direction.

Besides, universities committed to sustainable development play a decisive role in ensuring that the socio-economic context in which they act moves in the same direction. Universities are a hotbed of innovations in research, developed with a collaborative networking approach, and transferred to stakeholders. Hence, the need for innovative research should be even more oriented towards SDGs and thus towards sustainable development: universities have a significant impact on the socioeconomic scenario thanks to their high level of specialization and professional human resource profile.

If the key role played by universities with regard to the diffusion of the sustainability and SD principles in civil society is clear, through a permanent dialogue with the sociopolitical actors, it should not be overlooked that universities must make their campuses and structures green and sustainable. Green campuses have always been considered as the starting point on the path towards the sustainable development of a university; for this reason, on a global level, many universities have taken measures intending to improve their environmental performance [69].

Thus, what is expected in the near future is that universities, increasingly aware of their role on the social level, could adopt organizational and management models that aim at promoting concrete strategies and actions for sustainable development in all processes, planning projects for the diffusion and promotion of its intrinsic value within the community and on the territory.

In our opinion, the challenge is still open for complex, polycentric, and multi-stakeholder organizations to seize the opportunities of the 2030 Agenda to promote new institutional governance mechanisms, to consistently guide internal decision-making processes, the allocation of resources, organizational redesign, and the incentives system for teaching and research; to actively influence the political and institutional processes to tracing the development trajectory of a sustainable society.

In this scenario, this work can provide useful input for the integration of the SDGs in the overall university system. In fact, universities of the sample can contribute to the implementation of the SDGs by providing best practices, which can guide other academic institutions in the integration of sustainability into their strategic pillars (e.g., education, research, operations and governance, and external leadership) [70].

\subsection{Limitations and Future Research}

This study, although capable of providing interesting reflections on the transposition of the principles of sustainability into the Italian university system, has some limitations.

The first limitation refers to the documentation we analyzed. Reports and plans are both important tools for organizational accountability and performance evaluation, and at the same time offer a great opportunity for universities that engage with the SDGs. In fact, the SDGs provide an excellent opportunity to inspire, organize, and integrate university reports and plans, and to showcase and celebrate the impact and importance of what universities do for global and local wellbeing; nonetheless, with reference to the SDGs, reporting and planning are still in development. 
From a methodological point of view, it should be pointed out that the advantages of using the content analysis consist in giving evidence of the effective adoption of general principles by the organizations. Narratives and the allocation of resources to their concrete implementation represent fundamental moments for transposing a general principle into measurable goals in space and time. At the same time, the content analysis is not able to standardize the data collected for the purpose of an effective comparison. The lack of control variables, and mechanisms useful for the standardization of data referable to very different realities, represent limits for this and other comparative research. In particular, content analysis involves a preliminary coding phase that was carried out by the research group. It is inevitable in such situations that the results would be conditioned by the researchers and interpreters. Furthermore, the documentation we investigated is produced by universities for purposes other than our specific research topics; this implies the emergence of a further intrinsic research limitation. The documentation existed prior to the analysis and could therefore have some information gaps. Moreover, the use of institutional documents poses a problem of self-referencing by organization, sometimes finalized to create a good reputation towards stakeholders [66,71,72].

To overcome these research limitations, research scenarios in future could better analyze the transposition of the sustainability principles into different areas of interest in the Italian university system by a longitudinal analysis that compares the current strategic planning contents and sustainability reporting with subsequent documents published by universities.

This present work gives only the results of the first stage of our research. The second step in field investigation will interview government and academics actors at Italian universities, using a questionnaire based on the Agenda 2030 pillars.

The self-referencing limitation we mentioned leads to reflection that gives us a final research question: is it possible that many universities endorse the SDGs publicly with specific declarations, but that, in fact, this behavior may be ceremonial, or even a type of confidence trick [73] aimed to legitimize their actions? This would result in formal compliance programs that are a kind of 'window dressing' [74,75], having the purpose of apparently meeting the social requests and increasing the external perception of legitimacy, while allowing the organization to be managed just as before.

This reflection identifies further space for future research on the topic.

Author Contributions: The article is the result of the joint work of the authors. In the editing phase, P.D.N. oversaw Sections 2 and 5.1; M.M.-Sections 3 and 6; E.I.-Section 4.1, Section 5.2, and Section 6.1; C.N.-Sections 1, 4 and 5 . All authors have read and agreed to the published version of the manuscript.

Funding: This research received no external funding.

Conflicts of Interest: The authors declare no conflict of interest.

\section{References}

1. Ramísio, P.J.; Pinto, L.M.C.; Gouveia, N.; Costa, H.; Arezes, D. Sustainability Strategy in Higher Education Institutions: Lessons learned from a nine-year case study. J. Clean. Prod. 2019, 222, 300-309. [CrossRef]

2. Alhaddi, H. Triple bottom line and sustainability: A literature review. Bus. Manag. Stud. 2015, 1, 6-10. [CrossRef]

3. Köksal, D.; Strähle, J.; Müller, M.; Freise, M. Social sustainable supply chain management in the textile and apparel industry. A literature review. Sustainability 2017, 9, 100. [CrossRef]

4. Murphy, K. The social pillar of sustainable development: A literature review and framework for policy analysis. Sustain. Sci. Pr. Policy 2012, 8, 15-29. [CrossRef]

5. Eustachio, J.H.P.P.; Caldana, A.C.F.; Will, M.; Salvia, A.L.; Rampasso, I.S.; Anholon, R.; Kovaleva, M. Sustainability Leadership in Higher Education Institutions: An Overview of Challenges. Sustainability 2020, 12, 3761. [CrossRef]

6. Shiel, C.; Smith, N.; Cantarello, E. Aligning campus strategy with the SDGs: An institutional case study. In Universities as Living Labs for Sustainable Development; Springer: Cham, Switzerland, 2020; pp. 11-27. [CrossRef] 
7. Barile, S.; Saviano, M.; Polese, F.; Di Nauta, P. Il rapporto impresa-territorio tra efficienza locale, efficacia di contesto e sostenibilità ambientale (The Firm-Territory Relationship between Local Efficiency, Context Effectiveness and Environmental Sustainability). Sinergie Ital. J. Manag. 2013, 25-49. [CrossRef]

8. Nigro, C.; Iannuzzi, E.; Petracca, M. How universities institutionalize 'good' managerial practices? Some evidence on the Italian cultural sector. Sinergie Ital. J. Manag. 2018, 100, 39-55. [CrossRef]

9. Di Nauta, P.; Merola, B.; Caputo, F.; Evangelista, F. Reflections on the role of university to face the challenges of knowledge society for the local economic development. J. Knowl. Econ. 2015, 9, 180-198. [CrossRef]

10. Barile, S.; Di Nauta, P.; Caputo, F. A path towards an evolutionary interpretation of the education service in Italian Universities. A systems variety perspective. In Cybernetics and Systems. Social and Business Decisions; Barile, S., Espejo, R., Perko, I., Saviano, M., Eds.; Systems Management Bool Series by Routledge-Giappichelli; Routledge: Abingdon, UK, 2018; pp. 241-245. [CrossRef]

11. Barth, M.; Rieckmann, M. Academic staff development as a catalyst for curriculum change towards education for sustainable development: An output perspective. J. Clean. Prod. 2012, 26, 28-36. [CrossRef]

12. Leal Filho, W.; Wu, Y.C.J.; Brandli, L.L.; Avila, L.V.; Azeiteiro, U.M.; Caeiro, S.; Madruga, L.R.D.R.G. Identifying and overcoming obstacles to the implementation of sustainable development at universities. J. Integr. Environ. Sci. 2017, 14, 93-108. [CrossRef]

13. Vilalta, J.M.; Betts, A.; Gómez, V. Higher Education's role in the 2030 agenda: The why and how of GUNi's commitment to the SDGs. In Sustainable Development Goals: Actors and Implementation. A Report from the International Conference; GUNI: Barcelona, Spain, 2018; Available online: http://www.acup.cat/sites/default/ files/2018-06/Higher\%20Education\%27s\%20Role.pdf (accessed on 1 September 2020).

14. de Amorim, W.S.; da Silva Neiva, S.; Castro, B.C.G.; Deggau, A.B.; Jonck, A.V.; de Albuquerque Junior, C.L.; de Andrade, J.B.S.O. Higher Education Institutions as Drivers of Sustainable Communities: A Case Study of the University of Southern Santa Catarina Empowering the Community. In Universities and Sustainable Communities: Meeting the Goals of the Agenda 2030; Springer: Cham, Switzerland, 2020; pp. 805-823. [CrossRef]

15. Persico, M.G.; Rossi, F. Comunicare la sostenibilità. In Comunicare il Nuovo Paradigma per un Nuovo Vantaggio Competitivo; Franco Angeli: Milan, Italy, 2016.

16. Von Hauff, M.; Nguyen, T. Universities as potential actors for sustainable development. Sustainability 2014, 6, 3043-3063. [CrossRef]

17. Wright, T.S. Definitions and frameworks for environmental sustainability in higher education. High. Educ. Policy 2002, 15, 105-120. [CrossRef]

18. Buonaura, C.C.; Di Nauta, P. An approach to accreditation: The path of the Italian Higher Education. In Proceedings of the ENQUA Workshop on Accreditation Models in Higher Education, Rome, Italy, 12-15 November 2003.

19. Mochizuki, Y.; Fadeeva, Z. Competences for sustainable development and sustainability. Int. J. Sustain. High. Educ. 2010, 11, 391-403. [CrossRef]

20. Yarime, M.; Trencher, G.; Mino, T.; Scholz, R.W.; Olsson, L.; Ness, B.; Rotmans, J. Establishing sustainability science in higher education institutions: Towards an integration of academic development, institutionalization, and stakeholder collaborations. Sustain. Sci. 2012, 7, 101-113. [CrossRef]

21. Scalia, M.; Barile, S.; Saviano, M.; Farioli, F. Governance for sustainability: A triple-helix model. Sustain. Sci. 2018, 13, 1235-1244. [CrossRef]

22. Frondizi, R.; Fantauzzi, C.; Colasanti, N.; Fiorani, G. The evaluation of universities' third mission and intellectual Capital: Theoretical analysis and application to Italy. Sustainability 2019, 11, 3455. [CrossRef]

23. United Nations. Transforming our World: The 2030 Agenda for Sustainable Development, Resolution Adopted by the General Assembly. 2015. Available online: www.sustainabledevelopment.un.org/post2015/ transformingourworld (accessed on 1 September 2020).

24. Mori Junior, R.; Fien, J.; Horne, R. Implementing the UN SDGs in universities: Challenges, opportunities, and lessons learned. Sustain. J. Rec. 2019, 12, 129-133. [CrossRef]

25. Morcellini, M. Per un'università sostenibile e moderna. Uno" sguardo sociologico" sulla valutazione e sull'ANVUR. RIV Rass. Ital. Valutazione 2016, 68-82. [CrossRef]

26. Marimon, F.; del Mar Alonso-Almeida, M.; del Pilar Rodríguez, M.; Alejandro, K.A.C. The worldwide diffusion of the global reporting initiative: What is the point? J. Clean. Prod. 2012, 33, 132-144. [CrossRef] 
27. Lozano, R.; Lukman, R.; Lozano, F.J.; Huisingh, D.; Lambrechts, W. Declarations for sustainability in higher education: Becoming better leaders, through addressing the university system. J. Clean. Prod. 2013, 48, 10-19. [CrossRef]

28. del Mar Alonso-Almeida, M.; Marimon, F.; Casani, F.; Rodriguez-Pomeda, J. Diffusion of sustainability reporting in universities: Current situation and future perspectives. J. Clean. Prod. 2015, 106, 144-154. [CrossRef]

29. Moggi, S. Il Sustainability Reporting Nelle Università; Maggioli Editore: Rome, Italy, 2016.

30. Lozano, R.; Ceulemans, K.; Alonso-Almeida, M.; Huisingh, D.; Lozano, F.J.; Waas, T.; Lambrechts, W.; Lukman, R.; Hugé, J. A review of commitment and implementation of sustainable development in higher education: Results from a worldwide survey. J. Clean. Prod. 2015, 108, 1-18. [CrossRef]

31. Oyama, K.; Pasquier, A.G.; Mojica, E. Transition to Sustainability in Macro-Universities: The Experience of the National Autonomous University of Mexico (UNAM). Sustainability 2018, 10, 4840. [CrossRef]

32. Sefa Dei, G.J.; Turay, T.M. Book Review: John Huckle and Stephen Sterling (eds.), Education for Sustainability (London: Earthscan Publications, 1996. 236 pp). Millenn. J. Int. Stud. 1997, 26, 543-546. [CrossRef]

33. Sterling, S. Higher education, sustainability, and the role of systemic learning. In Higher Education and the Challenge of Sustainability; Springer: Dordrecht, The Netherlands, 2004; pp. 49-70. [CrossRef]

34. Ryan, A.; Cotton, D. Times of Change: Shifting Pedagogy and Curricula for Future Sustainability. In The Sustainable University: Progress and Prospects; Earthscan: London, UK, 2013; pp. 151-167. [CrossRef]

35. Veiga Ávila, L.; Rossato Facco, A.L.; Bento, M.H.D.S.; Arigony, M.M.; Obregon, S.L.; Trevisan, M. Sustainability and education for sustainability: An analysis of publications from the last decade. Environ. Qual. Manag. 2018, 27, 107-118. [CrossRef]

36. Lozano, R.; Barreiro-Gen, M.; Lozano, F.; Sammalisto, K. Teaching Sustainability in European Higher Education Institutions: Assessing the Connections between Competences and Pedagogical Approaches. Sustainability 2019, 11, 1602. [CrossRef]

37. Ramos, T.B.; Caeiro, S.; van Hoof, B.; Lozano, R.; Huisingh, D.; Ceulemans, K. Experiences from the implementation of sustainable development in higher education institutions: Environmental Management for Sustainable Universities. J. Clean. Prod. 2015, 106, 3-10. [CrossRef]

38. Findler, F.; Schönherr, N.; Lozano, R.; Reider, D.; Martinuzzi, A. The impacts of higher education institutions on sustainable development. Int. J. Sustain. High. Educ. 2019, 20, 23-38. [CrossRef]

39. Findler, F.; Schönherr, N.; Lozano, R.; Stacherl, B. Assessing the impacts of higher education institutions on sustainable development-An analysis of tools and indicators. Sustainability 2018, 11, 59. [CrossRef]

40. Butlin, J. Our common future. By World commission on environment and development. (London, Oxford University Press, 1987). J. Int. Dev. 1989, 1, 284-287. [CrossRef]

41. Atkinson, G. Measuring corporate sustainability. J. Environ. Plan. Manag. 2000, 43, 235-252. [CrossRef]

42. Reinhardt, F.L. Sustainability and the firm. INFORMS J. Appl. Anal. 2000, 30, 26-41. [CrossRef]

43. Rees, W.E. An ecological economics perspective on sustainability and prospects for ending poverty. Popul. Environ. 2002, 24, 15-46. [CrossRef]

44. Lozano, R. Analysing the use of tools, initiatives, and approaches to promote sustainability in corporations. Corp. Soc. Responsib. Environ. Manag. 2019, 27, 982-998. [CrossRef]

45. Elkington, J. The Triple Bottom Line. In Environmental Management: Readings and Cases; Sage: Thousand Oaks, CA, USA, 1997; p. 2.

46. Holden, E.; Linnerud, K.; Banister, D. Sustainable development: Our common future revisited. Glob. Environ. Chang. 2014, 26, 130-139. [CrossRef]

47. The Sustainable Development Agenda: 17 Goals for People, for Planet. Available online: https://sustainabledevelopment.un.org (accessed on 1 September 2020).

48. Ferrer-Balas, D.; Adachi, J.; Banas, S.; Davidson, C.I.; Hoshikoshi, A.; Mishra, A.; Ostwald, M. An international comparative analysis of sustainability transformation across seven universities. Int. J. Sustain. High. Educ. 2008, 9, 295-316. [CrossRef]

49. Shiel, C.; Williams, A. Working together, driven apart: Reflecting on a joint endeavour to address sustainable development within a university. In Integrative Approaches to Sustainable Development at University Level; Springer: Cham, Switzerland, 2015; pp. 425-447. [CrossRef] 
50. Blanco-Portela, N.; Benayas, J.; Pertierra, L.R.; Lozano, R. Towards the integration of sustainability in higher education institutions: A review of drivers of and barriers to organisational change and their comparison against those found of companies. J. Clean. Prod. 2017, 166, 563-578. [CrossRef]

51. Berry, F.S. Innovation in public management: The adoption of strategic planning. Public Adm. Rev. 1994, 54, 322. [CrossRef]

52. Bryson, J.M. Strategic planning and management. Handb. Public Adm. 2012, 38-47. [CrossRef]

53. Leal Filho, W.; Skanavis, C.; Kounani, A.; Brandli, L.L.; Shiel, C.; do Paco, A.; Salvia, A.L. The role of planning in implementing sustainable development in a higher education context. J. Clean. Prod. 2019, 235, 678-687. [CrossRef]

54. Lozano, R.; Lozano, F.J.; Mulder, K.; Huisingh, D.; Waas, T. Advancing higher education for sustainable development: International insights and critical re-flections. J. Clean. Prod. 2013, 48, 3-9. [CrossRef]

55. Paletta, A.; Siboni, B.; Bonoli, A.; Gallina Toschi, T. La sostenibilità come strategia di sviluppo degli atenei: Il caso dell'università di bologna. Impresa Progetto. Electron. J. Manag. 2018, 1, 1-14. Available online: https://www.impresaprogetto.it/sites/impresaprogetto.it/files/articles/ipejm_-_1-2018_-_paletta.pdf (accessed on 1 September 2020).

56. Sisto, R.; Sica, E.; Cappelletti, G.M. Drafting the Strategy for Sustainability in Universities: A Backcasting Approach. Sustainability 2020, 12, 4288. [CrossRef]

57. Saviano, M.; Barile, S.; Farioli, F.; Orecchini, F. Strengthening the science-policy-industry interface for progressing toward sustainability: A systems thinking view. Sustain. Sci. 2019, 14, 1549-1564. [CrossRef]

58. Van Kerkhoff, L. Knowledge governance for sustainable development: A review. Chall. Sustain. 2014, 1, 82-93. [CrossRef]

59. Agrifoglio, R.; Metallo, C.; Di Nauta, P. Understanding Knowledge Management in Public Organizations through the Organizational Knowing Perspective: A Systematic Literature Review and Bibliometric Analysis. Public Organ. Rev. 2020, 1-20. [CrossRef]

60. Van der Leeuw, S.; Wiek, A.; Harlow, J.; Buizer, J. How much time do we have? Urgency and rhetoric in sustainability science. Sustain. Sci. 2012, 7, 115-120. [CrossRef]

61. Tilbury, D.; Wortman, D. How is community education contributing to sustainability in practice? Appl. Environ. Educ. Commun. 2008, 7, 83-93. [CrossRef]

62. Cotton, D.; Bailey, I.; Warren, M.; Bissell, S. Revolutions and second-best solutions: Education for sustainable development in higher education. Stud. High. Educ. 2009, 34, 719-733. [CrossRef]

63. Cebrián, G.; Junyent, M. Competencies in education for sustainable development: Exploring the student teachers' views. Sustainability 2015, 7, 2768-2786. [CrossRef]

64. Stemler, S. An overview of content analysis. Pract. Assess. Res. Eval. 2000, 7, 17.

65. Krippendorff, K. Reliability in Content Analysis: Some Common Misconceptions and Recommendations. Hum. Commun. Res. 2004, 30, 411-433. [CrossRef]

66. Corbetta, P. Social Research: Theory, Methods and Techniques; Sage: Thousand Oaks, CA, USA, 2003. [CrossRef]

67. Scott, J. Documentary Research; Sage: Thousand Oaks, CA, USA, 2006. [CrossRef]

68. Kestin, T.; van den Belt, M.; Denby, L.; Ross, K.E.; Thwaites, J.; Hawkes, M. Getting started with the SDGs in universities: A guide for universities, higher education institutions, and the academic sector. Australia, New Zealand and Pacific Edition. 2017. Available online: http://ap-unsdsn.org/wp-content/uploads/UniversitySDG-Guide_web.pdf (accessed on 1 September 2020).

69. Sharp, L. Green campuses: The road from little victories to systemic transformation. Int. J. Sustain. High. Educ. 2002, 3, 128-145. [CrossRef]

70. Körfgen, A.; Förster, K.; Glatz, I.; Maier, S.; Becsi, B.; Meyer, A.; Kromp-Kolb, H.; Stötter, J. It's a Hit! Mapping Austrian Research Contributions to the Sustainable Development Goals. Sustainability 2018, 10, 3295. [CrossRef]

71. Vollero, A.; Palazzo, M.; Siano, A.; Elving, W.J.L. Avoiding the greenwashing trap: Between CSR communication and stakeholder engagement. Int. J. Innov. Sustain. Dev. 2016, 10, 120. [CrossRef]

72. Cuomo, M.T.; Metallo, G.; Tortora, D.; Siano, A.; Vollero, A.; Kitchen, P.J. Solid Green and Greenwashing: When Is Communication Really Green? Micro Macro Mark. 2015, 24, 463-486.

73. Pfeffer, J. Power in Organizations; Ballinger Pub. Co.: Pensacola, FL, USA, 1981. 
74. Nigro, C.; Iannuzzi, E. Navigating managerial decision-making processes between competition, asymmetric information, isomorphism, legitimacy, decoupling, manipulation, power and cynicism. Cybern. Syst. 2018, 91-95. [CrossRef]

75. Nigro, C.; Iannuzzi, E.; Petracca, M. Isomorphic and decoupling processes: An empirical analysis of governance in Italian state museums. Sinergie Ital. J. Manag. 2018, 99, 241-262. [CrossRef]

(C) 2020 by the authors. Licensee MDPI, Basel, Switzerland. This article is an open access article distributed under the terms and conditions of the Creative Commons Attribution (CC BY) license (http://creativecommons.org/licenses/by/4.0/). 